\title{
Inhibitory Activity of Hydrosols, Herbal Teas and Related Essential Oils Against Filament Formation and the Growth of Candida albicans
}

\author{
Shigeharu Inouye, Miki Takahashi, Shigeru Abe \\ Teikyo University Institute of Medical Mycology
}

〔Received: 2, March 2009. Accepted: 15, June 2009〕

\begin{abstract}
The antifungal activity of 43 hydrosols, 7 herbal teas and 12 essential oils was determined using Candida albicans as a test organism. All of the hydrosols examined showed more potent inhibition against the filamentous form than the yeast form of $C$. albicans. In particular, the filamentous form was markedly inhibited by seven hydrosols, of which monarda, santolina and clove water also inhibited the growth of the yeast form. Most of the inhibitory activity of the hydrosols was correlated with that of their respective major components. Poor correlation was observed between the inhibition of filament formation and the growth inhibition of the yeast form among the hydrosols examined, among essential oils and among the major components of hydrosols and essential oils. Seven herbal teas showed moderate or weak activity against the filament formation of $C$. albicans, but no inhibition against the yeast form.
\end{abstract}

Key words : hydrosol, essential oil, herbal tea, antifungal activity, filamentous form

\section{Introduction}

Hydrosol is obtained by steam distillation of aromatic herbs together with essential oils, and is used mainly in the cosmetic field and less frequently in the medical field. Scientific evaluation of hydrosols is necessary before medical application, but little work has been published so far. Herbal teas including green tea are consumed as beverages to prevent various disorders, and the pharmacological activity of polyphenols contained in tea water has been a subject of considerable research. However, little on the antibacterial activity of hydrosols and herbal teas has been reported ${ }^{1,2)}$, and no report has been published on the antifungal activity in either English or Japanese literature.

Candida albicans is one of the major fungal pathogens causing oral and vaginal candidiasis and systemic infection which has frequently recurred in the immunocompromised patients. Candida strains resistant to antifungal agents are also increasing. $C$.

Address for correspondence : Shigeharu Inouye

Teikyo University Institute of Medical Mycology

359 Otsuka, Hachioji, Tokyo 192-0395, Japan albicans shows dimorphism, the filamentous (mycelial) form and the yeast form, in which the filamentous form is more pathogenic than the yeast form ${ }^{3,4}$. In this report, we would like to report the antifungal activity of 43 hydrosols against both filamentous and yeast forms of $C$. albicans in vitro, for possible application as an antiseptic mouthwash. The antifungal activity of 7 herbal teas which are an aqueous solution similar to hydrosols was also examined, together with the related 12 essential oils.

\section{Materials and methods}

\section{Preparation of hydrosol and essential oil}

Twenty-nine hydrosols and two essential oils were supplied by Kenso Igakusha, Ltd., Yamanashi, Japan, which had been obtained by steam distillation of the herbs cultivated on a Yamanashi farm. Twelve hydrosols and 5 essential oils were prepared by steam distillation of the herbs cultivated on a Chichibu farm, Saitama, Japan. Some hydrosols were obtained from wild plants growing in Yamanashi and Chichibu districts, and 2 hydrosols and 5 essential oils were from Pranarom, Belgium. The source of each of these is indicated in Table 1, and their composition was reported 
Table 1. Inhibitory effect of 43 hydrosols against the filamentous formation and growth of C. albicans

\begin{tabular}{|c|c|c|c|c|c|c|}
\hline \multirow{2}{*}{$\begin{array}{l}\text { Hydrosol } \\
\text { (parent plant, location) }\end{array}$} & \multirow{2}{*}{$\begin{array}{l}\text { Major component } \\
\text { (concentration, } \mu \mathrm{g} / \mathrm{ml} \text { ) }\end{array}$} & \multicolumn{3}{|c|}{ Filament formation } & Inhibitory & \multirow{2}{*}{$\begin{array}{c}\text { Yeast form } \\
\text { Growth } \\
\text { inhibition }(\%)\end{array}$} \\
\hline & & $1 \mathrm{x}$ & $5 \mathrm{x}$ & $10 x^{* *}$ & effect & \\
\hline $\begin{array}{l}\text { Lemongrass } \\
\qquad \text { (Cymbopogon citratus) } \\
\text { (Yamanashi) }\end{array}$ & citral（61） & $99.3 \pm 2.49$ & $82.0 \pm 7.35$ & & +++ & $<10$ \\
\hline $\begin{array}{l}\text { Lemon verbena } \\
\qquad \text { (Lippia citriodora) } \\
\quad \text { (Yamanashi) }\end{array}$ & citral（74） & $99.3 \pm 3.30$ & $95.5 \pm 0.73$ & & +++ & $<10$ \\
\hline $\begin{array}{l}\text { Lemon balm } \\
\qquad \text { (Mellissa officinalis) } \\
\text { (Yamanashi) }\end{array}$ & citral（13） & $94.7 \pm 3.30$ & $60.7 \pm 4.19$ & & ++ & $<10$ \\
\hline $\begin{array}{l}\text { Tea tree lemon } \\
\text { (Leptospermum pertersoni } \\
\text { (Yamanashi) }\end{array}$ & citral (152) & $95.7 \pm 4.92$ & $98.2 \pm 0.46$ & & +++ & $<10$ \\
\hline $\begin{array}{l}\text { Perilla (shiso) } \\
\text { (Perilla frutescens var. cris } \\
\quad \text { (Yamanashi) }\end{array}$ & $\begin{array}{l}\text { perillaldehyde (99) } \\
\text { pa) }\end{array}$ & $91.0 \pm 3.27$ & $54.7 \pm 4.11$ & & ++ & $<10$ \\
\hline $\begin{array}{l}\text { Lemon eucalyptus } \\
\qquad \text { (Eucalyptus citriodora) } \\
\text { (Yamanashi) }\end{array}$ & $\begin{array}{l}\text { p-menthane-3,8-diol }(87) \\
\text { citronellal }(26)\end{array}$ & $98.9 \pm 0.82$ & $57.7 \pm 17.6$ & & ++ & $<10$ \\
\hline $\begin{array}{l}\text { Rose geranium } \\
\quad \text { (Pelargonium asperum) } \\
\quad \text { (Yamanashi) }\end{array}$ & $\beta$-ctronellol & $99.0 \pm 0.82$ & $96.0 \pm 0.82$ & & +++ & $<10$ \\
\hline $\begin{array}{l}\text { Rose } \\
\qquad \text { (Rosa damascena) } \\
\quad \text { (Yamanashi) }\end{array}$ & phenethyl alcohol (33) & $72.3 \pm 5.25$ & $4.0 \pm 2.83$ & & \pm & $<10$ \\
\hline $\begin{array}{l}\text { Peppermint } \\
\qquad \text { (Mentha piperita) } \\
\quad \text { (Yamanashi) }\end{array}$ & menthol (139) & $81.3 \pm 2.87$ & $38.3 \pm 9.43$ & & + & $<10$ \\
\hline $\begin{array}{l}\text { Japanese peppermint } \\
\text { (Mentha arvensis) } \\
\text { (Yamanashi) }\end{array}$ & menthol (185) & $69.3 \pm 3.68$ & $\mathrm{nt}$ & & \pm & $<10$ \\
\hline $\begin{array}{l}\text { Lavender } \\
\qquad \text { (Lavandula angustifolia) } \\
\quad \text { (Yamanashi) }\end{array}$ & linalool (54) & $100.0 \pm 0.05$ & $57.7 \pm 7.76$ & & ++ & $<10$ \\
\hline $\begin{array}{l}\text { Bergamot mint } \\
\quad \text { (Mentha citrata) } \\
\quad \text { (Yamanashi) }\end{array}$ & linalool (90) & $99.0 \pm 0.82$ & $60.3 \pm 2.05$ & & ++ & $<10$ \\
\hline $\begin{array}{l}\text { Neroli } \\
\quad \text { (Citrus aurantium spp.am } \\
\quad \text { (Pranarom) }\end{array}$ & $\begin{array}{l}\text { linalool (190) } \\
\text { ara) }\end{array}$ & $98.0 \pm 1.63$ & $89.0 \pm 3.27$ & & +++ & $<10$ \\
\hline $\begin{array}{l}\text { Kuromoji } \\
\quad \text { (Lindera umbellata }) \\
\quad \text { (Chichibu) }\end{array}$ & linalool (580) & $101.3 \pm 1.25$ & $102.3 \pm 7.13$ & $77^{* *}$ & +++ & $<10$ \\
\hline $\begin{array}{l}\text { Yuzu } \\
\qquad \text { (Citrus junos) } \\
\quad \text { (Yamanashi) }\end{array}$ & linalool (34) & $93.7 \pm 0.60$ & $58.7 \pm 0.94$ & & ++ & $<10$ \\
\hline $\begin{array}{l}\text { Tea tree } \\
\qquad \text { (Melaleuca alternifolia) } \\
\text { (Yamanashi) }\end{array}$ & terpinen-4-ol (98) & $87.0 \pm 1.63$ & $19.0 \pm 13.06$ & & + & $<10$ \\
\hline $\begin{array}{l}\text { St. John's wort } \\
\text { (Hypericum perforatum) } \\
\text { (Yamanashi) }\end{array}$ & terpinen-4-ol (1.4) & $58.3 \pm 11.0$ & nt & & \pm & $<10$ \\
\hline Echinacea & terpinen-4-ol（5.9） & $27.3 \pm 3.67$ & nt & & - & $<10$ \\
\hline
\end{tabular}

(Echinacea purpurea)

(Chichibu) 


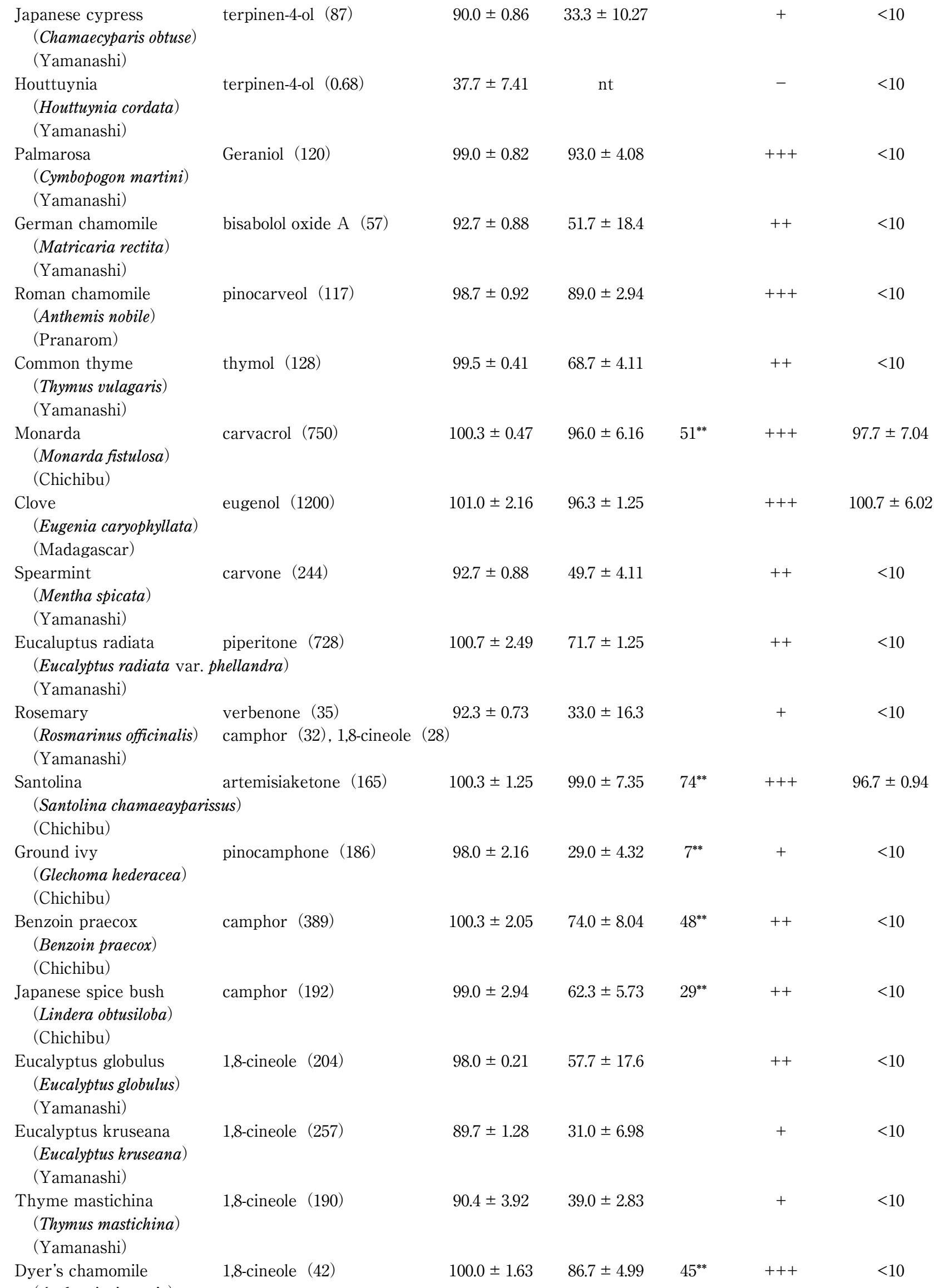

(Anthemis tinctoria)

(Chichibu) 


\begin{tabular}{|c|c|c|c|c|c|c|}
\hline $\begin{array}{l}\text { Japanese mugwort } \\
\text { (Artemisia princeps) } \\
\text { (Yamanashi) }\end{array}$ & 1,8-cineole（18） & $77.3 \pm 5.31$ & nt & & \pm & $<10$ \\
\hline $\begin{array}{l}\text { Tansy } \\
\qquad \text { (Tanacetum vulgare }) \\
\text { (Chichibu) }\end{array}$ & chrysanthenyl acetate (500) & $100.3 \pm 1.25$ & $55.0 \pm 8.16$ & & ++ & $22.7 \pm 6.13$ \\
\hline $\begin{array}{l}\text { Manuka } \\
\text { (Leptospermum scoparium } \\
\text { (Yamanashi) }\end{array}$ & methyl cinnamate (4.7) & $81.3 \pm 3.68$ & nt & & + & $<10$ \\
\hline $\begin{array}{l}\text { Thoroughwort } \\
\text { (Eupatorium japonicum) } \\
\text { (Chichibu) }\end{array}$ & thymolmethylether (51) & $101.0 \pm 2.16$ & $84.7 \pm 1.25$ & $48^{* *}$ & +++ & $14.0 \pm 4.97$ \\
\hline $\begin{array}{l}\text { Hyssopleaf thoroughwort } \\
\text { (Eupatorium laciniatum) } \\
\text { (Chichibu) }\end{array}$ & coumarin (87) & $99.3 \pm 3.30$ & $97.0 \pm 1.41$ & $67^{* *}$ & +++ & $24.3 \pm 8.22$ \\
\hline $\begin{array}{l}\text { Perilla } \\
\qquad \text { (Perilla frutescens) } \\
\quad \text { (Chichibu) }\end{array}$ & myristicin (74) & $98.0 \pm 2.45$ & $95.7 \pm 0.94$ & $28^{* *}$ & +++ & $<10$ \\
\hline
\end{tabular}

\begin{tabular}{lcc}
\multicolumn{3}{l}{ Foot note of Table 1} \\
\hline $\begin{array}{ll}\text { Definition of inhibitory effect: } \\
\text { Effect }\end{array}$ & \multicolumn{2}{l}{ Inhibitory rate } \\
& $<50 \%$ & $5 \mathrm{x}$ \\
\hline- & $>50 \%$ & \\
\pm & $>80 \%$ & \\
+ & $>80 \%$ & $>50 \%$ \\
++ & $>90 \%$ & $>80 \%$ \\
+++ &
\end{tabular}

in a previous paper ${ }^{5)}$. Pure chemical compounds were purchased from Tokyo Kasei Kogyo, Ltd., Tokyo, and Wako Pure Chemical Industries, Ltd., Osaka.

Preparation of herbal tea

Dried herbs of lemongrass, German chamomile, thyme, spearmint and rosemary were prepared in China and imported through S \& B Foods Inc., Tokyo. Dried rose petals prepared in France and dried lemon balm herb prepared in Spain were imported through St. Louis International Inc., Tokyo. A dried herb (2 g) was immersed in boiling hot water (100 ml, $2 \mathrm{w} / \mathrm{v} \%)$, and stood at room temperature for $10 \mathrm{~min}$. Then, the extract was decanted through a filter paper (Advantec, Toyo Roshi Kaisha, Ltd., Tokyo), and the filtrate was kept in a cold room at $4{ }^{\circ} \mathrm{C}$ until use. The extract was approximately ten to twenty times more concentrated than that used at home. The volatile composition of herbal teas was analyzed by the procedure reported earier ${ }^{5}$, using the solvent extraction method with ethyl acetate followed by gas chromatographic analysis. The major volatile components are listed in Table 4 .

\section{Fungal strain}

C. albicans TIMM 1678 was a stock strain of Teikyo University Institute of Medical Mycology. This strain is able to form the filamentous cells (germ tube) in a medium containing serum.

Inhibitory assay of filamentous form of $C$. albicans The assay was carried out according to Abe et al. ${ }^{6}$ ) with slight modification. Hydrosol $(100 \mu \mathrm{l})$ or herbal tea $(100 \mu \mathrm{l})$ and RPMI 1640 broth $(100 \mu \mathrm{l})$ containing $2.0 \%$ calf serum and $C$. albicans (500 cells/well) were mixed in a 96 well flat microplate. The mixture was cultured at $37^{\circ} \mathrm{C}$ under $5 \% \mathrm{CO}_{2}$ atmosphere for 16 h. Inhibition of filament formation was observed by a light microscope $(40 \mathrm{x})$. Microbes showing the filamentous form were adsorbed on the wall of the microplate. After the yeast form was washed out with distilled water, the plate was treated with $70 \%$ ethanol to kill the remaining cells and washed with saline. The filamentous cells adsorbed on the wall were stained with $0.02 \%$ crystal violet $(10 \mu \mathrm{l})$ for $15 \mathrm{~min}$. After washing out excess dye with water, the dye adsorbed on the cells was eluted with isopropanol $(150 \mu \mathrm{l})$ containing $0.25 \%$ dodecyl sulfate and $0.04 \mathrm{~N}$ hydrochloric acid, and the absorbance at $620 \mathrm{~nm}$ of the extract was recorded using a multiscan photometer (Labsystems Multiskan Bichromatic, Dainippon Seiyaku Ltd., Osaka). The inhibitory rate of filamentous formation was expressed as follows:

Inhibitory rate $(\%)=\left(1-\mathrm{OD}_{\text {sample }} / \mathrm{OD}_{\text {control }}\right) \times 100$

An average and SD of three determinations is recorded in Table 1.

An essential oil or pure component was dissolved in DMSO in two-fold dilutions starting from $320 \mathrm{mg} / \mathrm{ml}$ to $0.038 \mathrm{mg} / \mathrm{ml}$. Each DMSO solution was diluted 200 


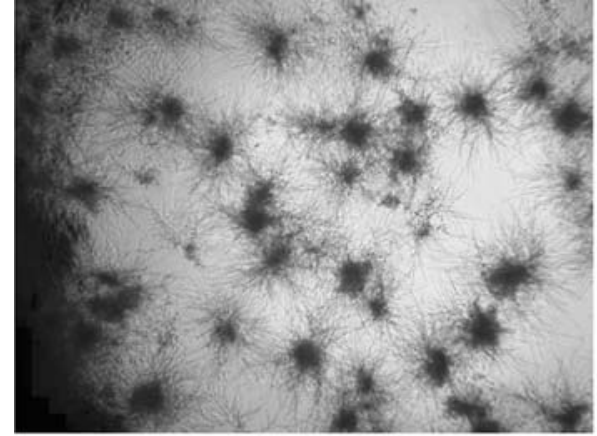

Tea tree water ( 5 -fold dilution )

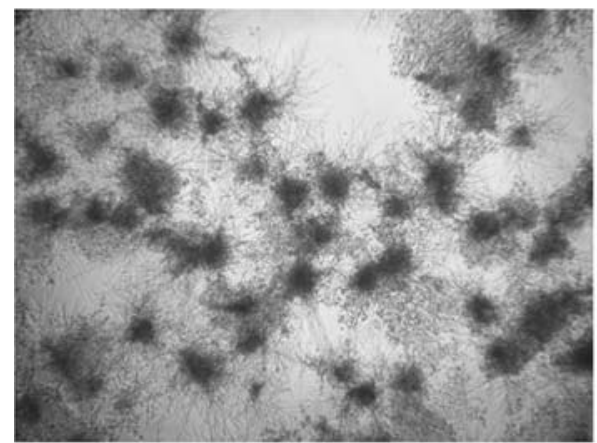

Lavender water ( 5 -fold dilution )

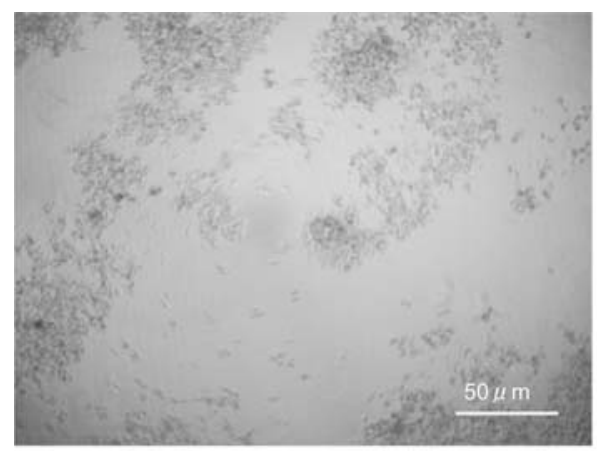

Clove water ( 5 -fold dilution )

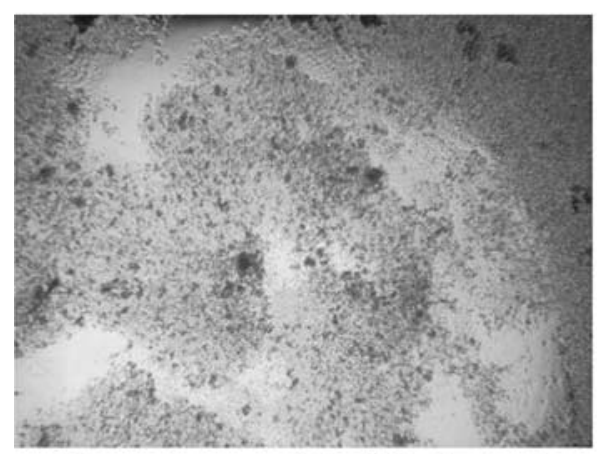

Monarda water ( 5 -fold dilution )

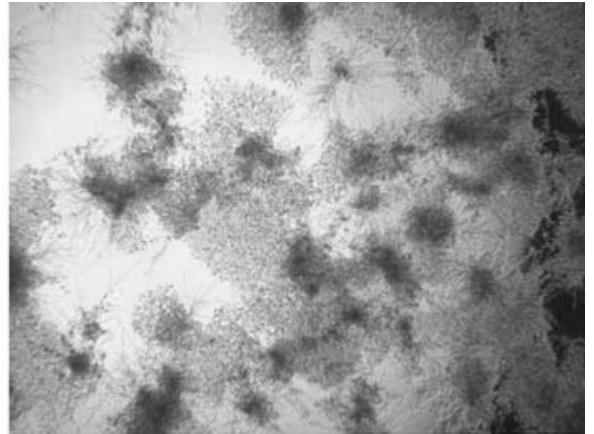

Lemongrass water ( 5 -fold dilution )

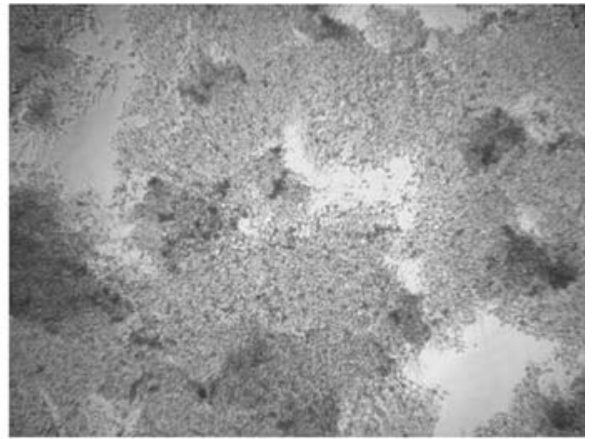

Rose geranium water ( 5 -fold dilution )

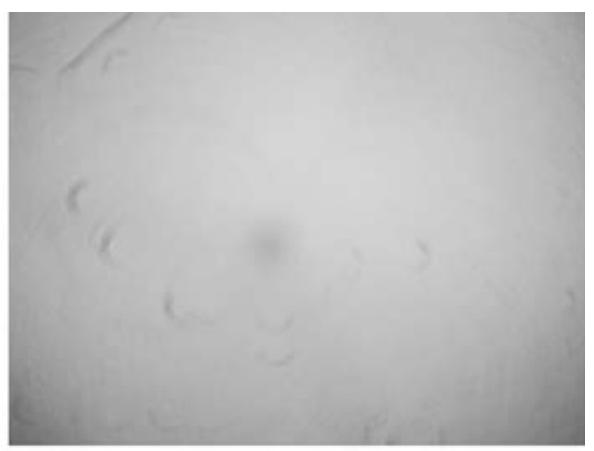

Clove water ( original solution )

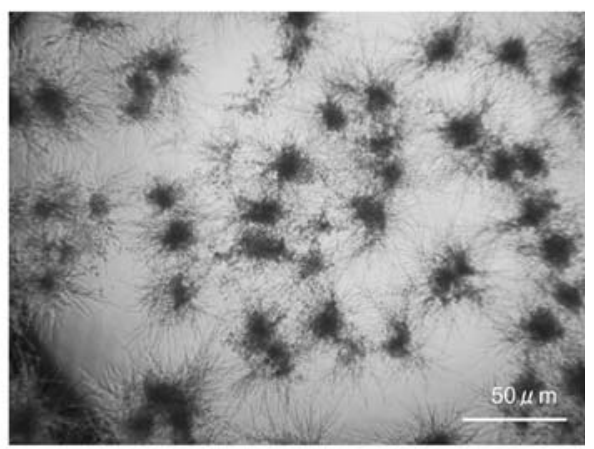

Non-treated control

Fig. 1. Inhibitory effect of 6 hydrosols on the filamentous formation of $C$. albicans. Star-like clusters are the filamentous form, and small round particles are the yeast form. The inhibitory percentage (\%) of five-fold diluted hydrosols are shown below in parenthesis.

Tea tree water $(19 \%)$, lavender water $(58 \%)$, lemongrass water $(82 \%)$, rose geranium water $(96 \%)$, clove water $(96 \%)$, monarda water $(96 \%)$, and non-treated control $(0 \%)$. Clove water without dilution suppressed the growth of both filamentous and yeast forms. 
times with RPMI 1640 medium containing calf serum. The final concentration of DMSO was $0.25 \%$, which did not affect the filament formation of the fungi. The inhibitory activity of oil or constituent was determined according to the procedure described for hydrosols. The activity was expressed by the $\mathrm{IC}_{50}$ value (a drug concentration to exhibit 50\% inhibition), obtained from at least three determinations of different concentrations including $\mathrm{IC}_{50}$ level.

\section{Assay for antifungal activity}

The growth-inhibitory activity of hydrosols, herbal teas and essential oils against the yeast form of $C$. albicans was determined using RPMI 1640 medium according to the micro broth dilution assay recommended by NCCLS M-27-A ${ }^{7}$. Four fresh colonies grown on the Sabouroud dextrose agar plate were suspended in sterile saline and the turbidity was adjusted to $0.5 \mathrm{McF}$ arland $\left(1 \times 10^{6} \mathrm{cells} / \mathrm{ml}\right)$. This was diluted with RPMI1640 medium to obtain a fungal suspension for assay $\left(2 \times 10^{3}\right.$ cells $\left./ \mathrm{ml}\right)$. A mixture of the fungal suspension $(100 \mu \mathrm{l})$ and a hydrosol $(100 \mu \mathrm{l})$ or herbal tea $(100 \mu \mathrm{l})$ was added to a well, and incubated at $30^{\circ} \mathrm{C}$ for $48 \mathrm{hr}$ until the absorbance at $620 \mathrm{~nm}$ of the non-treated control well exceeded 0.2. Since some of the herbal teas were colored, the colored solution without microbes was used as the non-treated control. An inhibitory percentage was calculated by the following equation:

Inhibition $(\%)=\left(1-\mathrm{OD}_{\text {sample }} / \mathrm{OD}_{\text {control }}\right) \times 100$

An inhibition of less than $10 \%$ was defined as ineffective, and an average and SD of three determinations above a $10 \%$ inhibition percentage are listed in Table 1. MIC was defined as the minimum concentration showing an inhibition percentage of more than $80 \%\left(\mathrm{IC}_{80}\right)$. An essential oil or pure component was dissolved in DMSO in two-fold dilutions starting from $320 \mathrm{mg} / \mathrm{ml}$ to $0.038 \mathrm{mg} / \mathrm{ml}$. Each DMSO solution was diluted 100-fold with RPMI 1640. The final concentration of DMSO in the MIC determination was $0.5 \%$, which did not affect the growth of the fungi.

\section{Results}

\section{Inhibitory effect of hydrosol on the filament for-} mation of C. albicans

Figure 1 illustrates the inhibition of the filamentous form of $C$. albicans by hydrosols using a light microscope. The control figure shows only the filamentous form of $C$. albicans. When diluted 5 times, tea tree and lavender water showed moderate inhibition, lemongrass water strong inhibition, and rose geranium, clove and monarda water very strong inhibition. When the filamentous form was decreased by the action of hydrosol, the yeast form was increased as seen by the particles. Non-diluted clove water suppressed the growth of both the filamentous and yeast forms.

Table 1 shows the inhibitory effect of 43 hydrosols, together with the respective parent plant names, source of hydrosols and major components. Inhibitory effect was expressed by none $(-)$, negligible $( \pm)$, weak $(+)$, moderate $(++)$ and strong $(+++)$ according to the definition shown in the footnote of the table. Although most of the hydrosols examined inhibited formation of the filamentous form to some degree, the highest activity was shown by 15 hydrosols: that is, lemongrass, lemon verbena, tea tree lemon, rose geranium, neroli, kuromoji, palmarosa, Roman chamomile, monarda, clove, santolina, Dyer's chamomile, thoroughwort, hyssopleaf thoroughwort and perilla water. These hydrosols showed more than $80 \%$ inhibition even after 5-fold dilution. Kuromoji, santolina and hyssopleaf thoroughwort water exhibited more than 50\% inhibition even after 10-fold dilution.

Only three hydrosols, monarda, santolina and clove water, showed complete inhibition $(96 \sim 100 \%)$ of the growth of the yeast form of $C$. albicans (Table 1). Hyssopleaf thoroughwort, tansy and thoroughwort water showed slight inhibition ( $14 \sim 24 \%$ ), but other hydrosols did not show any significant inhibition $(<10 \%)$ of the yeast form.

Parallel to hydrosols, we have determined the inhibitory activity of major components of hydrosols, as shown in Table 2. The most potent inhibition against filament formation was demonstrated by citral $\left(\mathrm{IC}_{50}, 3.13 \mu \mathrm{g} / \mathrm{ml}\right)$ which is a major component of lemongrass, lemon verbena and tea tree lemon water, geraniol $(12.5 \mu \mathrm{g} / \mathrm{ml})$ a major component of palmarosa water, and citronellol $(12.5 \mu \mathrm{g} / \mathrm{ml})$ a major one of rose geranium water. Perillaldehyde showed moderate inhibition $(25 \mu \mathrm{g} / \mathrm{ml})$. Linalool, thymol and carvacrol showed weak inhibition $(50 \mu \mathrm{g} / \mathrm{ml})$, and terpinen-4-ol, piperitone, coumarin, eugenol, menthol and 1,8-cineole were very weak or negligible in the inhibitory activity $(100 \sim>100 \mu \mathrm{g} / \mathrm{ml})$. Inhibition of the filamentous form resulted in increase of the yeast form (data are not shown).

Table 2 also shows the growth inhibition of the yeast form. Citral exhibited the highest inhibition (MIC, $50 \mu \mathrm{g} / \mathrm{ml}$ ), followed by perillaldehyde, thymol, and carvacrol $(100 \mu \mathrm{g} / \mathrm{ml})$, then geraniol and eugenol (400 $\mu \mathrm{g} / \mathrm{ml})$. Other components were weak in the activity. Thymoquinone and farnesol which are components of essential oils exhibited potent inhibition of both filamentous and yeast forms. Fluconazole used as a reference compound showed $\mathrm{IC}_{50}$ of $0.125 \mu \mathrm{g} / \mathrm{ml}$ for 
Table 2. Inhibitory effect of major components of hydrosols against filament formation and growth of $C$. albicans

\begin{tabular}{lcc}
\hline Component & Inhibitory dose $\left(\mathrm{IC}_{50}, \mu \mathrm{g} / \mathrm{ml}\right)$ & MIC $(\mu \mathrm{g} / \mathrm{ml})$ \\
\hline Citral & 3.13 & 50 \\
Geraniol & 12.5 & 400 \\
Citronellol & 12.5 & 800 \\
Perillaldehyde & 25 & 100 \\
Linalool & 50 & 1600 \\
Thymol & 50 & 100 \\
Carvacrol & 50 & 100 \\
Terpinen-4-ol & 100 & 1600 \\
Piperitone & 100 & $\mathrm{nt}$ \\
Coumarin & 100 & $>800$ \\
Eugenol & 200 & 400 \\
Menthol & $>100$ & 800 \\
1,8-Cineole & $>100$ & $>800$ \\
Thymoquinone & 3.13 & 25 \\
Farnesol $^{*}$ & 6.25 & 25 \\
Fluconazole $^{*}$ & 0.125 & 0.25 \\
\hline
\end{tabular}

nt: not tested ${ }^{*}$ a component of oil

Table 3. Inhibitory effect of 12 essential oils against filament formation and growth of yeast form of $C$. albicans

\begin{tabular}{llcc}
\hline Essential oil (Source) & Major component & $\mathrm{IC}_{50}(\mu \mathrm{g} / \mathrm{ml})$ & $\mathrm{MIC}(\mu \mathrm{g} / \mathrm{ml})$ \\
\hline Lemongrass (Yamanashi) & citral $(73.2 \%)^{*}$ & 3.13 & 400 \\
Rose geranium (Yamanashi) & citronellol (28.0\%) & 6.25 & $>800$ \\
German chamomile (Pranarom) & bisabolol oxide A (39.7\%) & 12.5 & $>800$ \\
Monarda (Chichibu) & thymoquinone (32.6\%) & 25 & 50 \\
Lavender (Pranarom) & linalool (44.8\%) & 100 & 3200 \\
Neroli (Pranarom) & linalool (35.0\%) & 100 & 8000 \\
Kuromoji (Chichibu) & linalool (41.8\%) & 100 & $>800$ \\
Thoroughwort (Chichibu) & thymolmethylether (31.8\%) & $>800$ \\
Hyssopleaf thoroughwort (Chichibu) & thymolmethylether (19.5\%) & 200 & $>800$ \\
Roman chamomile (Pranarom) & isobutyl angelate (34.9\%) & 200 & 400 \\
Clove (Pranarom) & eugenol (83.7\%) & 200 & $>800$ \\
Tansy (Chichibu) & chrysanthenyl acetate (54.5\%) & \\
\hline
\end{tabular}

* Figure in parenthesis indicates percentage of a major component against total amount of volatile components as estimated by a ratio of the peak area of a major component against total peak area in GC.

Table 4. Inhibitory effect of 7 herbal teas against filament formation and growth of yeast form of $C$. albicans

\begin{tabular}{|c|c|c|c|c|c|}
\hline \multirow{3}{*}{ Tea } & \multirow{3}{*}{$\begin{array}{l}\text { Major volatile component } \\
(\mu \mathrm{g} / \mathrm{ml})\end{array}$} & \multicolumn{3}{|c|}{ Inhibition rate $(\%)$} & \multirow{3}{*}{$\begin{array}{c}\text { Inhibition rate }(\%) \\
\text { Yeast form } \\
1 \mathrm{x}\end{array}$} \\
\hline & & \multicolumn{2}{|c|}{ Filament form } & \multirow[t]{2}{*}{ Effect } & \\
\hline & & $1 \mathrm{x}$ & $5 x$ & & \\
\hline Lemongrass & citral (78) & $91.3 \pm 5.31$ & $76.3 \pm 7.85$ & ++ & $10.0 \pm 3.53$ \\
\hline Thyme & thymol (70) & $91.7 \pm 5.73$ & $55.3 \pm 9.53$ & ++ & $<10$ \\
\hline Lemon balm & citral $(1.4)$ & $83.0 \pm 6.16$ & $9.3 \pm 4.92$ & + & $<10$ \\
\hline Rose & phenethyl alcohol (9.2) & $91.0 \pm 4.08$ & $12.3 \pm 4.50$ & + & $<10$ \\
\hline German chamomile & $\begin{array}{l}\text { bisabolol oxide A }(18) \\
\text { en-in-spiroether }(12)\end{array}$ & $95.3 \pm 4.11$ & $21.0 \pm 11.3$ & + & $<10$ \\
\hline Rosemary & 1,8-cineole (30), camphor (17) & $91.7 \pm 2.49$ & $19.0 \pm 11.4$ & + & $<10$ \\
\hline Spearmint & carvone $(29)$ & $86.3 \pm 6.34$ & $13.7 \pm 6.32$ & + & $<10$ \\
\hline
\end{tabular}

Definition of effect is shown in the footnote of Table 1. 
filament formation and MIC of $0.25 \mu \mathrm{g} / \mathrm{ml}$, but no conversion from filamentous form to yeast form was observed.

Table 3 shows the inhibitory effect against $C$. albicans of the 12 essential oils and the respective major components which were selected for activity comparison with the corresponding hydrosols showing potent or moderate inhibition. As judged from the $\mathrm{IC}_{50}$ values, lemongrass oil exhibited the most potent activity $(3.13 \mu \mathrm{g} / \mathrm{ml})$ followed by rose geranium $(6.25 \mu \mathrm{g} / \mathrm{ml})$ and German chamomile $(12.5 \mu \mathrm{g} / \mathrm{ml})$. This was followed by monarda $(25 \mu \mathrm{g} / \mathrm{ml})$ and neroli $(50 \mu \mathrm{g} / \mathrm{ml})$. Other essential oils including lavender, kuromoji, thoroughwort, and hyssopleaf thoroughwort, Roman chamomile, clove and tansy oils were weak in the activity. When compared with the corresponding MIC values, the filamentous formation was inhibited at a concentration $1 / 2 \sim 1 / 128$ lower than the respective MIC.

Table 4 shows the inhibitory effect of the 7 herbal teas against $C$. albicans, together with the respective major volatile components. Lemongrass and thyme teas showed moderate inhibition against the filament formation of $C$. albicans, and the other 5 teas showed weak inhibition. However, no significant inhibition was observed on the growth of the yeast form of C. albicans.

\section{Discussion}

The anti-Candida activity of the hydrosol has not been reported to date. Essential oils such as lemongrass $^{6)}$, tea tree $^{8)}$, and lavender ${ }^{9)}$ have been reported to inhibit formation of the filamentous form of $C$. albicans at low concentration below the MIC. The same was found to be true for hydrosols in this investigation. Thus, most of the hydrosols examined suppressed the formation of the filamentous form. A comparison of the inhibitory activity between the hydrosols and their major components revealed that the hydrosols containing potent components such as citral (lemongrass, lemon verbena, lemon balm, tea tree lemon), geraniol (palmarosa), and citronellol (rose geranium) also showed potent activity. Although the absolute concentration of the components was greatly varied by hydrosol, the hydrosols containing weakly active components such as terpinen-4-ol (tea tree, St. John's wort, echinacea, Japanese cypress, houttuynia), menthol (peppermint, Japanese peppermint), and 1,8-cineole (eucalyptus kruseana, thymus mastichina, Japanese mugwort) were also weak in the activity. This indicated that the major component was responsible for the inhibitory activity of the hydrosol.
Exceptions were eucalyptus globulus and Dyer's chamomile, which contained weakly active 1,8-cineole as a major component, but showed moderate or high activity, suggesting the contribution of minor components. The potent inhibitory activity of hyssopleaf thoroughwort could not be explained by the action of the major component, coumarin, since it was weak in the activity. The potent inhibitory activity of thoroughwort water could not be ascribed to thymolmethylether, since its essential oil containing more concentrated thymolmethylether than that of the hydrosols was weaker in the activity: the oil containing thymolmethylether at $31.8 \mu \mathrm{g} / \mathrm{ml}$ showed $50 \%$ inhibition (calculated from Table 3), while the hydrosol containing the same component at $5.1 \mu \mathrm{g} / \mathrm{ml}$ showed $48 \%$ inhibition (calculated from Table 1). The moderate activity of eucalyptus radiata may be due to the high content $(728 \mu \mathrm{g} / \mathrm{ml})$ of piperitone though it was weak in the activity.

The inhibitory activity of the essential oils of lemongrass, rose geranium, monarda, lavender, neroli, and kuromoji could be ascribed to that of the respective major components (citral, citronellol, thymoquinone and linalool).

Only 3 hydrosols (monarda, clove, santolina) inhibited the growth of the yeast form of $C$. albicans. The growth-inhibitory activity of monarda and clove water also could be ascribed to that of the major components, because monarda and clove water contained 750 $\mu \mathrm{g} / \mathrm{ml}$ of carvacrol and $1200 \mu \mathrm{g} / \mathrm{ml}$ of eugenol, respectively, which were much higher than the respective MICs $(100 \mu \mathrm{g} / \mathrm{ml}, 400 \mu \mathrm{g} / \mathrm{ml})$. It was not certain that artemisiaketone played a vital role in the activity of santolina water.

When compared with the corresponding essential oils (Table 3), both hydrosols and oils of lemongrass, rose geranium and monarda showed comparable and potent activity. The oil of German chamomile was more potent than that of the hydrosol, whereas the hydrosols of Roman chamomile, clove, thoroughwort and hyssopleaf thoroughwort were more potent than the corresponding oils. This indicated that the inhibitory activity of the hydrosols and oils were not always in parallel with each other.

When compared with the growth inhibition of the yeast form as shown by MIC and filament inhibition as shown by $\mathrm{IC}_{50}$ of various components (Table 2), no clear correlation was observed. Thus, thymol is more potent than geraniol and citronellol in the growth inhibition, but weaker than these components in the filament inhibition. Likewise, menthol was more potent than linalool, terpinen-4-ol and coumarin in the growth 
inhibition, but weaker in the filament inhibition. The discrepancy was also observed in cases of essential oils shown in Table 3 . Thus, rose geranium oil showed lower $\mathrm{IC}_{50}(6.25 \mu \mathrm{g} / \mathrm{ml})$ than monarda oil $(25 \mu \mathrm{g} / \mathrm{ml})$, but higher MIC $(>800 \mu \mathrm{g} / \mathrm{ml})$ than monarda $(50 \mu$ $\mathrm{g} / \mathrm{ml}$ ). German chamomile oil was potent in the filament inhibition but weak in the growth inhibition. Conversely, clove oil was weak in the filament inhibition but potent in the growth inhibition. The mechanism of action is probably different from each other for the inhibition of dimorphism and growth. However, components showing a MIC values below $100 \mu \mathrm{g} / \mathrm{ml}$ inhibited the filament formation at low concentration (3.15 $50 \mu \mathrm{g} / \mathrm{ml}$ ), suggesting mild correlation among the potent inhibitors.

When the herbal teas and the corresponding hydrosols were compared, they shared major volatile components in common, but the content of volatile component in the herbal teas was much less than that of the hydrosols. The comparatively weak antifungal activity of herbal teas to that of hydrosols was probably due to low content of the volatile components. Herbal teas contained non-volatile components such as polyphenols, polysaccharides and others. The weak activity of the teas suggested that non-volatile components might not contribute significantly to the antifungal activity.

It is well known that the filamentous form is responsible for the pathogenesis of the fungal infection ${ }^{3.4}$. Hisajima et $a l .^{10)}$ demonstrated that the filamentous form could penetrate the epithelial layer to cause infection, while the yeast form remained on the surface. Therefore, inhibition of the filamentous form may prevent the $C$. albicans infection such as oral and vaginal candidiasis. Indeed, Maruyama et al. ${ }^{11)}$ demonstrated that Candida cells in the vaginal cavity of mouse could change to the yeast form by washing with essential oils. Conversion of the filamentous form into the yeast form appeared to be characteristic of components of essential oils and hydrosols; the conversion was not observed with fluconazole. Furthermore, azole-resis$\operatorname{tant} C$. albicans was shown to have the ability to form hyphae from yeast cells in the presence of antifungal drugs $^{12)}$.

Since some of the hydrosols are still effective after five to ten-fold dilution, they may be used as they are or diluted with sterile water to rinse out the human mouth and vaginal cavity, and to gargle our throat to prevent Candida infection. Differing from essential oils, hydrosols are used to drink and apply to skin as they are, and they may be used safely as a mouthwash, though all the hydrosols might not be safe. However, we must confirm the inhibiting effect of hydrosol after a short period $(10 \sim 20$ seconds $)$ of exposure and duration of the inhibiting effect before their practical application.

As far as we examined, herbal teas are very weak in the antifungal activity. Furthermore, the concentration of teas we used was ten to twenty times more concentrated than the tea we use at home. Therefore, herbal teas may not be useful as an antiseptic.

In conclusion, the antifungal activity of 43 hydrosols, 7 herbal teas and 12 essential oils was determined against $C$. albicans. Three hydrosols inhibited the growth of C. albicans, and many hydrosols inhibited the formation of the filamentous form of $C$. albicans even after multiple dilutions.

\section{Acknowledgements}

The authors express their thanks to Mr. Kaoru Honobe of Kenso Igakusha, Ltd. Yamanashi for the supply of hydrosols and essential oils and for financial support of this research, Mrs Takako Miyara of CMC Research Laboratories, Meiji Seika Kaisha Ltd, Yokohama for analysis of GC/MS, and Ms Hiroko Ishibashi and Naho Maruyama of this laboratory for their kind teaching through this work.

\section{References}

1) Sagdic O, Ozcan M: Antibacterial activity of Turkish spice hydrosols. Food Control 14: 141-143, 2003.

2) Kim S, Ruengwilysup C, Fung DY: Antibacterial effect of water-soluble tea extracts on foodborne pathogens in laboratory medium and in a food model. J Food Prot 67: 2608-2612, 2004

3) Villar CC, Kashleva H, Dongari-Bagtzoglou A: Role of Candida albicans polymorphism in interactions with oral epithelia cells. Ora Microbiol Immunol 19: 262-269, 2004.

4) Salille SP, Lazzell AL, Bryant AP, et al. Inhibition of filamentation can be used to treat disseminated candidiasis. Antimicrob Agents Chemother 50: 3312-3316, 2006.

5) Inouye $S$, Takahasi $M, A b e ~ S$ : A comparative study on the composition of forty four hydrosols and their essential oils. Int J Essent Oil Ther 2: 89-104, 2008.

6) Abe $\mathrm{S}$, Sato $\mathrm{Y}$, Inoue $\mathrm{S}$ et al. Anti-Candida albicans activity of essential oils including lemongrass (Cymbopogon citratus) oil and its component, citral. Jpn J Med Mycol 44: 285-291, 2003.

7) National Committee for Clinical Laboratory Standards: Reference method for broth dilution antifungal susceptibility testing of yeasts. Approved Standard. NCCLS Document M27-A, NCCLS 17 (9), Vallanova, Pa, 1997.

8) Hammer KA, Carson CF, Riley TV: Melaleuca alternifolia (tea tree) oil inhibits germ tube formation by Candida albicans, Med Mycol 38: 355-362, 2000.

9) D'Auria FD, Tecca M, Strippoli U et al:: Antifungal activity of Lavandula angustifolia essential oil against 
Candida albicans yeast and mycelial form. Med Mycol 43: 391-396, 2005.

10) Hisajima $T$, Ishibashi $H$, Yamada $T$, et al. Invasion process of Candida albicans to tongue surface in early stages of experimental murine oral candidiasis. Med Mycol 46: 697-704, 2008.

11) Maruyama N, Takizawa $T$, Ishibashi $H$, et al:: Protective activity of geranium oil and its component, geraniol, in combination with vaginal washing against vaginal candidiasis in mice. Biol Pharm Bull 31: 1501-1506, 2008.

12) Ha KC, White TC: Effects of azole antifungal drugs on the transition from yeast cells to hyphae in susceptible and resistant isolates of the pathogenic yeast Candida albicans. Antimicrob Agents Chemother 43: 763-768, 1999. 